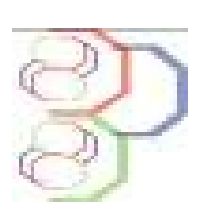

Journal of Applied Biosciences 129: 13708 - 13117

\title{
Analysis of the performance of a newly designed fermenter built in local materials for improvement of cocoa fermentation, in Ivory Coast
}

\author{
Aka S. Koffi ${ }^{*}$, N'Goran Yao1, Gilbert O. Sampson ${ }^{2}$, Honore G. Ouattara ${ }^{3}$, Denis Bruneau4 ${ }^{4}$, Kouakou \\ Konan ${ }^{5}$, Kadjo A. Diby 1 \\ ${ }^{1}$ Laboratory of Physics of Condensed Matter and Technology, UFR Sciences of the Structures of Matter and \\ Technology, Félix Houphouët-Boigny University of Cocody 22 B P 582, Abidjan, Côte d'Ivoire \\ ${ }^{2}$ Department of Hospitality and Tourism, University of Education, Winneba, College of Technology Education, \\ Kumasi-Ghana \\ ${ }^{3}$ Laboratoire de Biotechnologies, UFR Bisociences, Félix Houphouët-Boigny University of Cocody, 22 bp 582 \\ Abidjan, Côte d'Ivoire \\ 4/2M -UMR 5295-, department TREFLE, University of Bordeaux, 33405 Talence Cedex, France \\ ${ }^{5}$ Electricité et conversion d'énergie (ECEn) of Institut National polytechnique Félix Houphouet-Boigny of Côte d'Ivoire. \\ * Corresponding author: xastinaka@gmail.com
}

Keywords: cocoa fermentation, temperature, microbial activity, nib coloration

Original submitted in on $7^{\text {th }}$ June 2018. Published online at www.m.elewa.org on $30^{\text {th }}$ September 2018 http://dx.doi.org/10.4314/jab.v129i1.13

\begin{abstract}
Objective: Cocoa beans fermentation is a spontaneous chemical process, traditionally done in box or in a heap. Equipment is also important in achieving the final chocolate aroma. This study analyzes the performances of a new-designed cocoa bean fermenter.

Methodology and results: In this study, a new type of fermenter, a rotating cylindrical fermenter (RCF) has been designed in order to improve the fermentation of cocoa that remains difficult to control, because of the spontaneous nature of the microbiota. The performances of this fermenter was analyzed and compared to those of the traditional wooden box (TWB) fermenter that is commonly used on farm. During the 6 days of fermentation in both fermenters, the growth of microorganisms such as yeasts, lactic bacteria, acetic bacteria, bacillus and moulds as well as chemical and physical changes of the fermenting cocoa were monitored. The results showed that in the fermenter (RCF) a rapid temperature increase was observed in the course of the fermentation process with a temperature reaching $51^{\circ} \mathrm{C}$ within $73 \mathrm{~h}$ comparatively to the traditional fermenter $\left(48^{\circ} \mathrm{C}\right.$ within $\left.118 \mathrm{~h}\right)$. This leads to a higher proportion of brown beans, indicator of a good fermentation from RCF fermenter as assessed by the cut test. This proportion was $94.44 \%$ for RCF and $85.88 \%$ for TWB. Moreover the optimization of heat generated in the RCF fermenter, allowed a normal browning (final gray level was 77 in both fermenters) despite modification of microbiota growth order (early growth of acetic bacteria and stunted growth of yeast in RCF, but not for TWB).

Conclusion and application of results: The high proportions of brown beans in RCF suggest that this equipment is liable to contribute to the improvement of standard quality of cocoa beans.
\end{abstract}




\section{INTRODUCTION}

Cocoa (Theobroma cacao $\mathrm{L}$ ) beans are the main raw material for chocolate confection (TorresMoreno et al., 2015). The development of potential flavour and taste of future chocolate (Camu et al., 2008) involves two successive processes, the fermentation for chemical changes and drying for quality stabilization. Cocoa fermentation is a decisive step in the production of a quality chocolate, it depends strongly on the growth of the microbiota, which mainly include yeasts, lactic acid bacteria, acetic acid bacteria and Bacillus (De Vuyst and Weckx, 2016). Cocoa fermentation begins in anaerobic conditions with the development of yeasts, metabolizing sugar contained in the pulp into alcohol (Hamdouche, 2015). Yeasts also produce pulp degrading enzymes (pectinolytic enzymes) which allow the collapse of the pulp and subsequently, air percolation into the fermenting mass (Crafack et al., 2013; da Veiga Moreira et al., 2013). During this anaerobic phase, lactic acid bacteria oxidize the sugar into lactic acid. The alcoholic and lactic fermentation are accompanied by a slow increase of the heap temperature from $28-30^{\circ} \mathrm{C}$ (ambient temperature) to $35-40{ }^{\circ} \mathrm{C}$ (Hamdouche, 2015). Furthermore, as air is entering into the cocoa heaps, anaerobic conditions change into aerobic condition, which allow the growth of acetic acid bacteria. These bacteria are responsible for a sharp increase of the heap temperature by oxidizing ethanol into acetic acid, which is a heat producing reaction (Ouattara et al., 2014). The microbial activity taking place in the cocoa pulp, on the outer part of the beans results in the production of alcohol and acids that diffuse deep into beans and in combination with the heat, triggers endogenous reactions leading to the formations of aroma precursors molecules in the cotyledons (Nielsen et al., 2007). The quality of fermented cocoa bean depends strongly on microbial activity, which further depends on the fermenter design. The Fermenter offers environmental culture conditions, notably temperature and oxygen level necessary for microbial growth during cocoa fermentation. Hence, it should be designed in such a way to facilitate turning and airflow into the heaps but also to keep heat into the fermentation system. The design of the fermenter is therefore of great importance to achieve a good fermentation of cocoa beans (Guehi et al., 2010; Hatmi et al., 2015). The fermenter used to perform heaps fermentation with banana leaves or plastic are not able to keep tightly heat and the turning is laborious, taking long with important heat loss. In addition, the development of $L A B$ and moulds is easier in these fermenters (Bankoff et al., 2014). The fermenter in wooden box reduces heat loss and promotes more yeast growth (Bankoff et al., 2014), and the holes at the bottom of the box allow the liquid mucilage to flow out of the beans. In tray fermentation, several boxes are used in association (eight to ten boxes) in such a way to not require the turning. However, tray fermenter enhances air flow and induces important heat loss probably leading to the production of lactic acid with a negative result on cocoa quality (Barel, 2013; Nielsen et al., 2007).In order to simplify the turning operation, some producers use rotating wooden barrels, but the risk of mould growth is great, due to the confinement of humidity inside. The fermenter T60 incorporates in its design the favourable conditions to seeding phase of germs, the alcoholic phase and the acetic phase (Grimaldi, 1978). On the other hand, its implementation requires a lot of attention and a lot of wood. It should be interesting to design a fermenter modelling all the parameters and allow the production of good quality fermented cocoa beans in an automated way. The main objective of this study was to do a comparative analysis of the performance of a particular cocoa beans fermenter built in local materials with a traditional fermenter commonly used by farmers. 


\section{MATERIALS AND METHODS}

Ripe cocoa pods were obtained from cocoa plantations of the Agricultural Society of Bandama (SAB) in Côte $d^{\prime}$ Ivoire, in the village of M'Brimbo (latitude $6{ }^{\circ} 02$ " North and for longitude $4^{\circ} 54$ " West) during the two cocoa harvests of 2016. These pods are from different genotypes namely Trinitario, Forestero (amelonado) and Criollo.

\section{Methods}

Design and description of fermenter: In this study, two types of fermenters were used. The first, considered as the reference, is a traditional fermenter commonly used by farmers and the second, experimental fermenter specifically designed and intended to be an improved fermenter made from local materials. The reference or traditional fermenter is a cubic wooden box measuring $0.55 \mathrm{~m} 3$ of side with 150 $\mathrm{kg}$ fresh beans capacity. The bottom is perforated to allow drainage of sweating and aeration. Under a hangar, this fermenter is put down on a cleat and separated about $10 \mathrm{~cm}$ from the ground. The turning operation consists of removing half of the beans from the fermenter and mixing each portion individually, followed by all beans being put back in the fermenter.
The experimental fermenter is cylindrical with $28 \mathrm{~cm}$ radius of circular cross section and the capacity is $150 \mathrm{~kg}$ of fresh cocoa beans. The height of cylinder $(1.44 \mathrm{~m})$ provides occupation of half of fermenter when it is in vertical position during replenishment and alcoholic phase. This height also makes it possible to have a small thickness of bean in vertical position during the acetic phase. The fermenter was made with wooden frame and its thermal insulation was allowed by coconut fibre, also it has two pairs of closing cover, one for topside and second for low side. In each pair of closing cover, one is made of woven rattan with grid to let airflow during turning in aerobic or acetic phase, and the second being airtight is associated to the first cover during anaerobic phase of fermentation. Besides the bottom, airtight cover has one hole to facilitate fermented sweating evacuation. In this fermenter, the turning process consists in removing the closing cover, then making the fermenter 2 rotations in opposite direction and putting back the closing cover and fermenter to vertical. Rotation was allowed by the tipping mechanism (Fig 1).

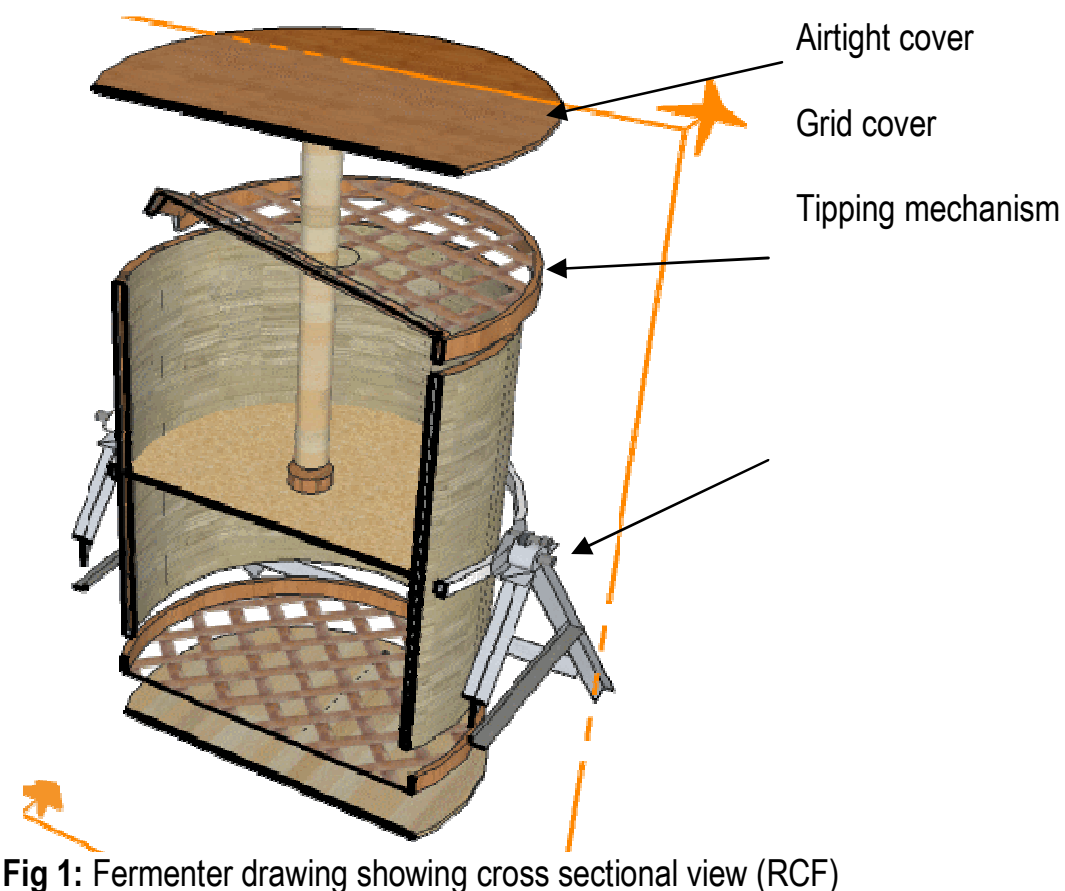

Fig 1: Fermenter drawing showing cross sectional view (RCF)

-Experiment design: Different genotypes of cocoa pods were harvested, collected and stored for up to 6 
days, then broken manually with a wooden bludgeon. The impaired beans such as germinated, not yet matured, aborted (flat) or damaged during pod opening, were discarded before, the rest of beans are put in plastic containers for transport to fermenter. Both fermenters were simultaneously filled with about $150 \mathrm{~kg}$ of beans fermented for six days (Fig 2). During fermentation, the experimental fermenter (RCF) and the reference fermenter (TWB) were turned according to the schedules fixed in the literature, in particular a turning each48 h (48 h, 96 hand $144 \mathrm{~h})$. The temperature in fermenting heap and the mass of the beans were measured directly (PT, FrBM, FeBM) and population of fermentation microbiota (NC) was measured indirectly after each sampling. This sampling was performed randomly from different zones in cocoa mass with a plastic probe (SP) with openings every $10 \mathrm{~cm}$ and introduced at fixed times $(0 \mathrm{~h}, 18 \mathrm{~h}, 28 \mathrm{~h}, 42$ h, 52 h, 66 h, 76 h, 91 h, 101 h, 114 h, 124 h and 140 h). For evaluation of beans quality by proportion of brown beans, each $48 \mathrm{~h}$ during fermentation sample was about $600 \mathrm{~g}$ and was drying directly on sun. Before fermentation both fermenter were sterilized in the same way and left unused for 7 days. The sterilization step consisted in spraying 10 liters of $1.2^{\circ}$ chlorinated water on fermenters followed by another spraying 2 hours later with $70 \%$ ethanol.

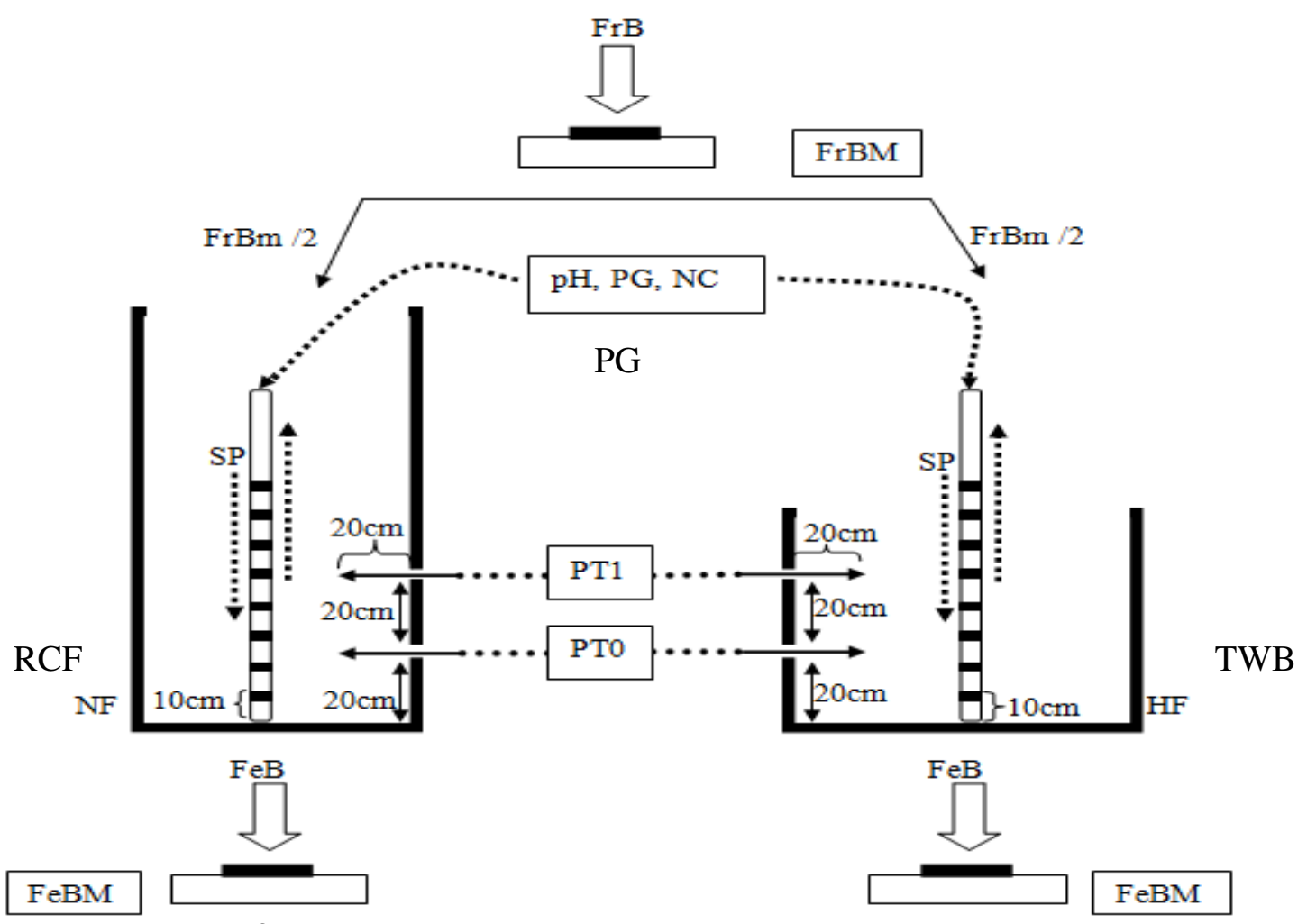

Fig 2: Description of experimental process

Legend

FrB Fresh beans

$\mathrm{SP} \quad$ Sampling probe

RCF New fermenter

TWB Hold fermenter

$\mathrm{FeB} \quad$ Beans after fermentation

\section{Quality control methods}

Temperature measurement: The temperature was continually monitored using a portable thermometer

$\begin{array}{ll}\text { FrBM } & \text { Inlet Fresh beans mass } \\ \text { PG } & \text { Population of germs } \\ \text { PT } & \text { Probe of temperature } \\ \text { FeBM } & \text { Fermented beans mass }\end{array}$

(Wimesure, Chevreuse, France) with the probes (Ti) plunging at $20 \mathrm{~cm}$ deep into the fermenting cocoa mass. The probes are connected to a data recorder 

materials for improvement of cocoa fermentation, in Ivory Coast

(ALMEMO 8590-9, Wimesure, France) which allows a continue recording of the temperature at one minute interval.

Microbial enumeration: At each sampling, $40 \mathrm{~g}$ were packed in a plastic stomacher and stored in a freezer until the end of the fermentation. Once all the samples of the fermentation are collected, they are transported with ice packs in a cooler over approximately $144 \mathrm{~km}$ to the laboratory for the counting of the microorganisms. The method of serial dilution was used to estimate the size of microorganism in the samples. Fresh cocoa bean sample $(10 \mathrm{~g})$ were added to $90 \mathrm{~mL}$ of $0.1 \%$ (w/v) buffered $(\mathrm{pH} 7.2)$ peptone water then let to rest in sterile flask, and shaken for 2 to $5 \mathrm{~min}$ at room temperature to obtain a homogenous sample containing the bacteria (initial dilution). One millilitre $(1.0 \mathrm{~mL})$ of the bacteria-enriched peptone water was diluted in $9 \mathrm{~mL}$ of $0.1 \%$ tryptone salt solution (10-fold dilution).A serial dilution up to $10^{-8}$ was performed from this solution then plated onto different media depending on the microorganism. Plates were incubated at $30^{\circ} \mathrm{C}$ for 48 to $72 \mathrm{~h}$ for colony count and microbial enumeration. Thus, a maximum of 10 isolates were randomly selected from two successive dilutions medium and analyzed.

Browning of nib measurement (CA): Each day, a sampling of $100 \mathrm{~g}$ are dried in the sun, at the end of the fermentation process and once all the samples were dry, the shell was removed and the nib was ground to a fine powder (Nielsen, 2006). Then the powders were classified according to the time of its fermentation. Photographs (Fig 5) of all the samples of the same fermentation were made and free software (ImageJ $1.45 \mathrm{~s}$ ) was used to evaluate the gray levels of each sample. Indeed, during the browning the tint of the almond darkens.

Cut test: This measure is related to the appreciation of the colour (slate, purple and brown) of the nib cut in half lengthwise. Both halves of each bean were examined in full daylight. It was made on 300 beans (Braudeau, 1973) taken from various places in the already dried cocoa bag. Results were expressed in percentage for each fermenter. Indeed, after fermentation, the beans were divided into two lots, one on open-air racks and another in a solar thermal dryer designed during this work but not presented in this article.

\section{RESULTS AND DISCUSSION \\ Modification in fermented mass during fermentation process Evaluation of the temperature:}

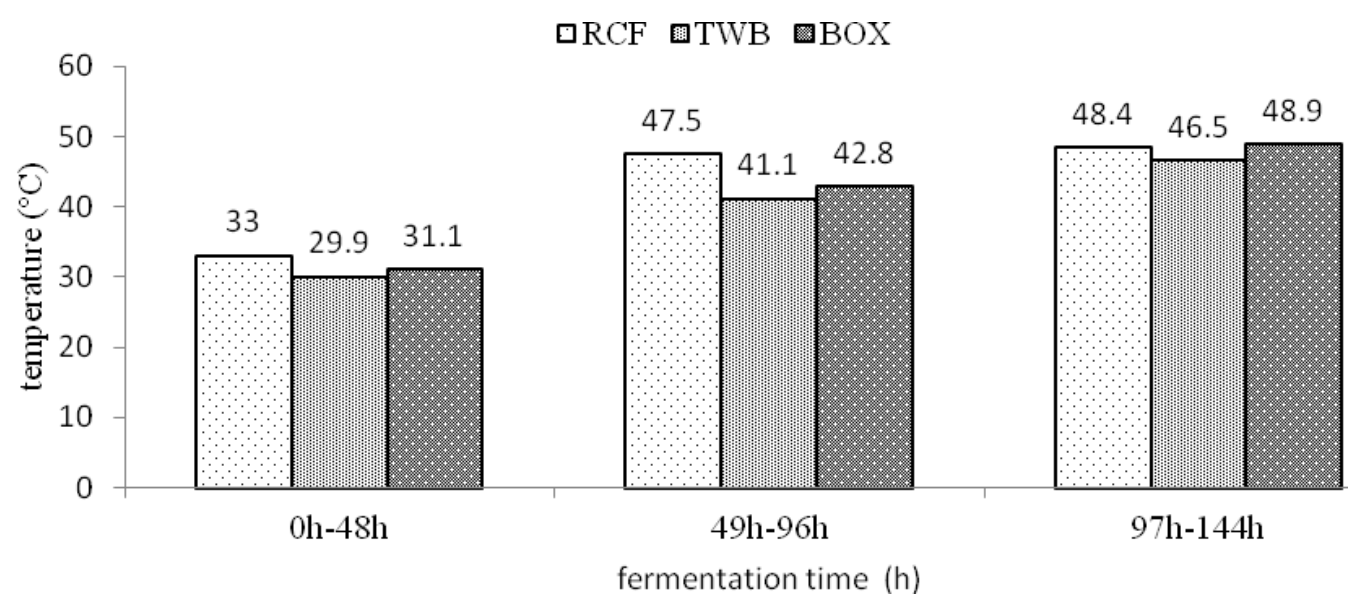

Fig 3: Average temperature in each fermenter after $48 \mathrm{~h}$ fermentation

Table 1: Highest values of temperature during fermentation as a function of time

\begin{tabular}{|c|c|c|c|c|c|c|}
\cline { 2 - 7 } \multicolumn{1}{c|}{} & \multicolumn{2}{c|}{ Oh to 48h } & \multicolumn{2}{c|}{$49 \mathrm{~h}$ to $96 \mathrm{~h}$} & \multicolumn{2}{c|}{$97 \mathrm{~h}$ to $144 \mathrm{~h}$} \\
\cline { 2 - 7 } \multicolumn{1}{c|}{} & $\begin{array}{c}\text { highest } \\
\text { value }\left({ }^{\circ} \mathrm{C}\right)\end{array}$ & Time $(\mathrm{h})$ & $\begin{array}{c}\text { highest } \\
\text { value }\left({ }^{\circ} \mathrm{C}\right)\end{array}$ & Time $(\mathrm{h})$ & $\begin{array}{c}\text { highest } \\
\text { value }\left({ }^{\circ} \mathrm{C}\right)\end{array}$ & Time (h) \\
\hline RCF & 41 & 48 & 51 & 73 & 50 & 110 \\
\hline TWB & 34 & 48 & 45 & 80 & 48 & 118 \\
\hline
\end{tabular}

13112 
Aka et al., J. Appl. Biosci. 2018 Analysis of the performance of a newly designed fermenter built in local materials for improvement of cocoa fermentation, in Ivory Coast

\begin{tabular}{|l|l|l|l|l|l|l} 
BOX & 35 & 48 & 47 & 96 & 50 & 102 \\
\hline
\end{tabular}

Results of average of temperature during fermentation for each fermenter are shown in Fig 3 . At the beginning of the fermentation, a temperature of $27^{\circ} \mathrm{C}$ was recorded in all three fermenters. Average temperatures were higher in RCF during all fermentation and between $49 \mathrm{~h}$ and $96 \mathrm{~h}$; the highest average value was reached. Coconut fibres used in RCF have a low thermal conductivity coefficient $(0.037 \mathrm{~W} / \mathrm{m} . \mathrm{K}<\lambda<0.045$ W/m.K) than solid wood $(0.14 \mathrm{~W} / \mathrm{m} . \mathrm{K}<\lambda<0.2 \mathrm{~W} / \mathrm{m} . \mathrm{K})$ used for TWB and BOX. The absence of opening on the wall of RCF eliminated the possibility of heat leakage induced by the air circulation, as observed in the other two fermenters. The high temperatures obtained in the fermenters are also explained by turning of mass without exit of beans, whereas in the other fermenter the beans must be obligatory exit. Dircks (2009) studies revealed that insulation of fermentation vessel coupled with minimal labour were key for optimum outcome. During the first 48 hours, the highest temperature was $41^{\circ} \mathrm{C}$ in $\mathrm{RCF}$, this is optimum temperature for polyphenol oxidase activity (Camu et al., 2008) for cocoa bean browning. Also $50^{\circ} \mathrm{C}$ were reached the fastest $(73 \mathrm{~h})$ in RCF, this temperature triggers endogenous enzymatic modification (Biehl et al., 1982) .Table 1 shows the highest temperature and time to have them

\section{Evaluation of bean quality after open-air drying}

Table 2: Cut test result of cacao beans each 48 hours of fermentation

\begin{tabular}{|c|l|c|c|c|c|c|}
\hline \multirow{4}{*}{ Time of fermentation } & Fermenter & $\begin{array}{c}\text { Brown } \\
(\%)\end{array}$ & $\begin{array}{c}\text { Purple } \\
(\%)\end{array}$ & $\begin{array}{c}\text { Germinated } \\
(\%)\end{array}$ & $\begin{array}{c}\text { Slaty } \\
(\%)\end{array}$ & $\begin{array}{c}\text { Mouldy } \\
(\%)\end{array}$ \\
\hline \multirow{4}{*}{$48 \mathrm{~h}$} & RCF & 68.18 & 21.59 & 2.27 & 2.27 & 5.68 \\
\cline { 2 - 7 } & TWB & 43.21 & 35.8 & 4.94 & 12.35 & 3.7 \\
\cline { 2 - 7 } & BOX & 59.52 & 25 & 0 & 15.47 & 0 \\
\hline \multirow{4}{*}{$96 \mathrm{~h}$} & RCF & 85.39 & 13.48 & 0 & 1.12 & 0 \\
\cline { 2 - 7 } & TWB & 78.31 & 18.07 & 2.41 & 1.2 & 0 \\
\cline { 2 - 7 } & BOX & 65.85 & 31.70 & 0 & 2.43 & 0 \\
\hline \multirow{4}{*}{$144 \mathrm{~h}$} & RCF & 94.44 & 4.44 & 0 & 1.11 & 0 \\
\cline { 2 - 7 } & TWB & 85.88 & 12.94 & 0 & 1.18 & 0 \\
\cline { 2 - 7 } & BOX & 89.53 & 9.3 & 0 & 1.16 & 0 \\
\hline
\end{tabular}

Results of cut test of beans during fermentation are shown in

Table 2. The proportion of brown beans increased with time of fermentation. For RCF, the value increase from $68.18 \%$ to $94.44 \%$, for TWB the value increase from $43.21 \%$ to $85.88 \%$ and for BOX the value increase from $59.52 \%$ to $89.53 \%$, respectively, at the end of fermentation. The change proportion of browning observed during fermentation in each fermenter was also observed by Kongor et al.(2013) and Nielsen (2006) and is due to the hydrolysis of anthocyanins which are pigments insoluble (tannins) in coloring (anthcyanidins). This hydrolysis increased throughout the fermentation with the increase in temperature and acidity in the nib. Indeed from $48 \mathrm{~h}$ the temperature of about $42^{\circ} \mathrm{C}$ was observed and the acidity entered in the almond will initiate the melting of the lipids (Biehl et al., 1982) and break the cell walls which isolated polyphenols (Barel, 2013). This action is likely to oxidized the polyphenol oxidases in the presence of air and subsequently complexed to produce tannin. This acidity of the nib with a pH of about 5 will promote the activity of the hydrolytic enzymes. This acidity of the nib with a pH of the activity of the hydrolytic enzymes will be upgraded(Biehl et al., 1993; Jinap, 1994; Afoakwa et al., 2013). This difference in the evolution of browning is explained by the difference in the temperature between the three fermenters. The decrease of proportion of germinated beans from $2.27 \%$ to $0 \%$ for the RCF and from $4.94 \%$ to $0 \%$ for the TWB, respectively, at the end of fermentation was showed on Table 1. This decrease 

materials for improvement of cocoa fermentation, in Ivory Coast

was due by the death of the germ after increase of temperature in fermentation heap and increase of beans acidity (Camu et al., 2008; Koffi et al., 2017). Germinated beans cannot develop the chocolate aroma during roasting (Kongor et al., 2013). The percentage of slaty beans was decrease with increasing fermentation time. For RCF the value decrease from $2.27 \%$ to Microbial behaviour during fermentation

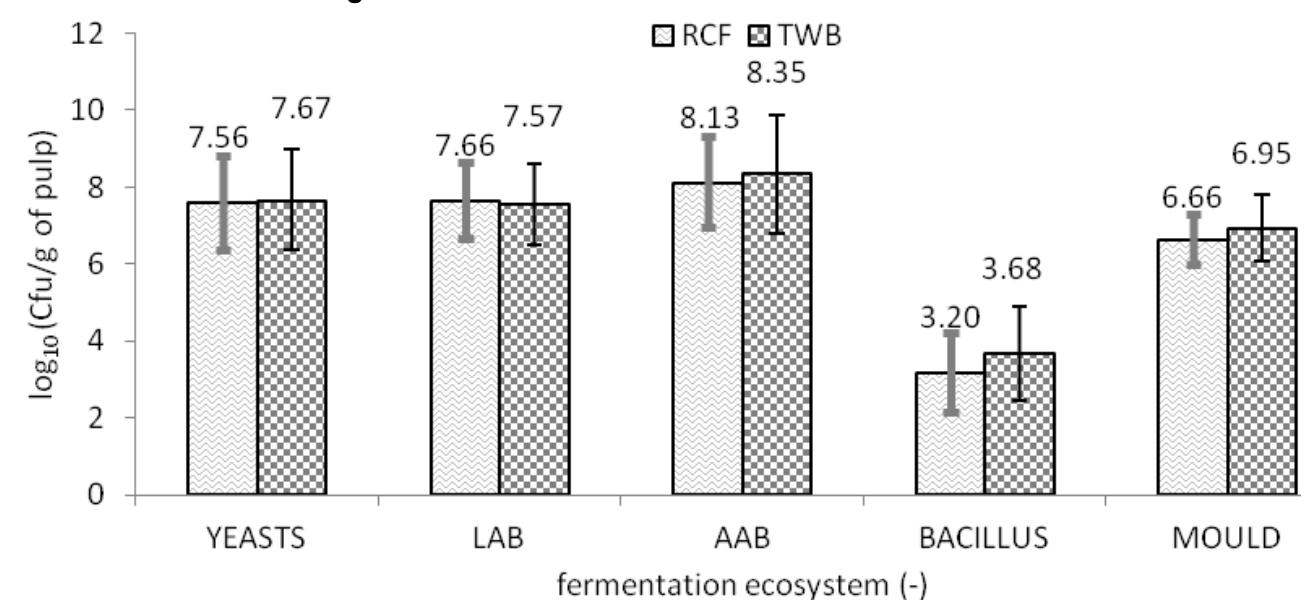

Fig 4 : Average population of microbiota in each fermenter during fermentation.

Table 3: Microbiota emergence value during normal fermentation in both fermenters

\begin{tabular}{|c|c|c|c|c|c|}
\cline { 2 - 6 } \multicolumn{1}{c|}{} & \multicolumn{5}{c|}{ Value inlog10 (CFU/g of pulp) } \\
\cline { 2 - 6 } \multicolumn{1}{c|}{} & Yeasts & LAB & AAB & Bacillus & Moulds \\
\hline RCF & 8.45 & 9.18 & 8.35 & 4.49 & 6.97 \\
\hline TWB & 7.91 & 9.43 & 9.05 & 4.97 & 6.67 \\
\hline Time $(\mathrm{h})$ & $<48$ & $<72$ & $>72$ & $>84$ & $>96$ \\
\hline
\end{tabular}

Fig 4 show average population of yeasts, $L A B, A A B$, bacillus and mould during fermentations. In both fermenters, population average values are similar with Hamdouche result (Hamdouche, 2015).

Table 3 show maximum value of each population during fermentations, values were different from those
$1.11 \%$, for TWB the value increase from $15.35 \%$ to 1.18 and for BOX the value increase from $15.47 \%$ to $1.16 \%$, respectively, at the end of fermentation. This decrease was due by turning and upgrade of fermentation (Guehi et al., 2010). Mouldy was only observed during the first 48 hours in RCF and TWB and the proportion was $5.68 \%$ for RCF and $3.70 \%$ for TWB.

\section{Microbial emergence timing and browning of nib during fermentation}

Table 4: Microbiota emergence value during abnormal fermentation only in RCF

\begin{tabular}{|c|c|c|c|c|c|c|c|c|c|c|}
\cline { 2 - 10 } \multicolumn{1}{c|}{} & \multicolumn{8}{c|}{ Value inlog 10 (CFU/g of pulp) } \\
\cline { 2 - 10 } & \multicolumn{2}{c|}{ YEASTS } & \multicolumn{2}{c|}{ LAB } & \multicolumn{2}{c|}{ AAB } & \multicolumn{2}{c|}{ BACILLUS } & \multicolumn{2}{c|}{ MOULDS } \\
\hline RCF & 8.14 & $90 \mathrm{~h}$ & 9.51 & $28 \mathrm{~h}$ & 9.14 & $28 \mathrm{~h}$ & 4.04 & $114 \mathrm{~h}$ & 5.90 & $\mathrm{Xh}$ \\
\hline TWB & 8.08 & $28 \mathrm{~h}$ & 9.46 & $28 \mathrm{~h}$ & 9.25 & $52 \mathrm{~h}$ & 4.90 & $124 \mathrm{~h}$ & 7.47 & $90 \mathrm{~h}$ \\
\hline time & \multicolumn{2}{|c|}{$<48 \mathrm{~h}$} & \multicolumn{2}{c|}{$<72 \mathrm{~h}$} & \multicolumn{2}{c|}{$>72 \mathrm{~h}$} & \multicolumn{2}{c|}{$>84 \mathrm{~h}$} & \multicolumn{2}{c|}{$>96 \mathrm{~h}$} \\
\hline
\end{tabular}



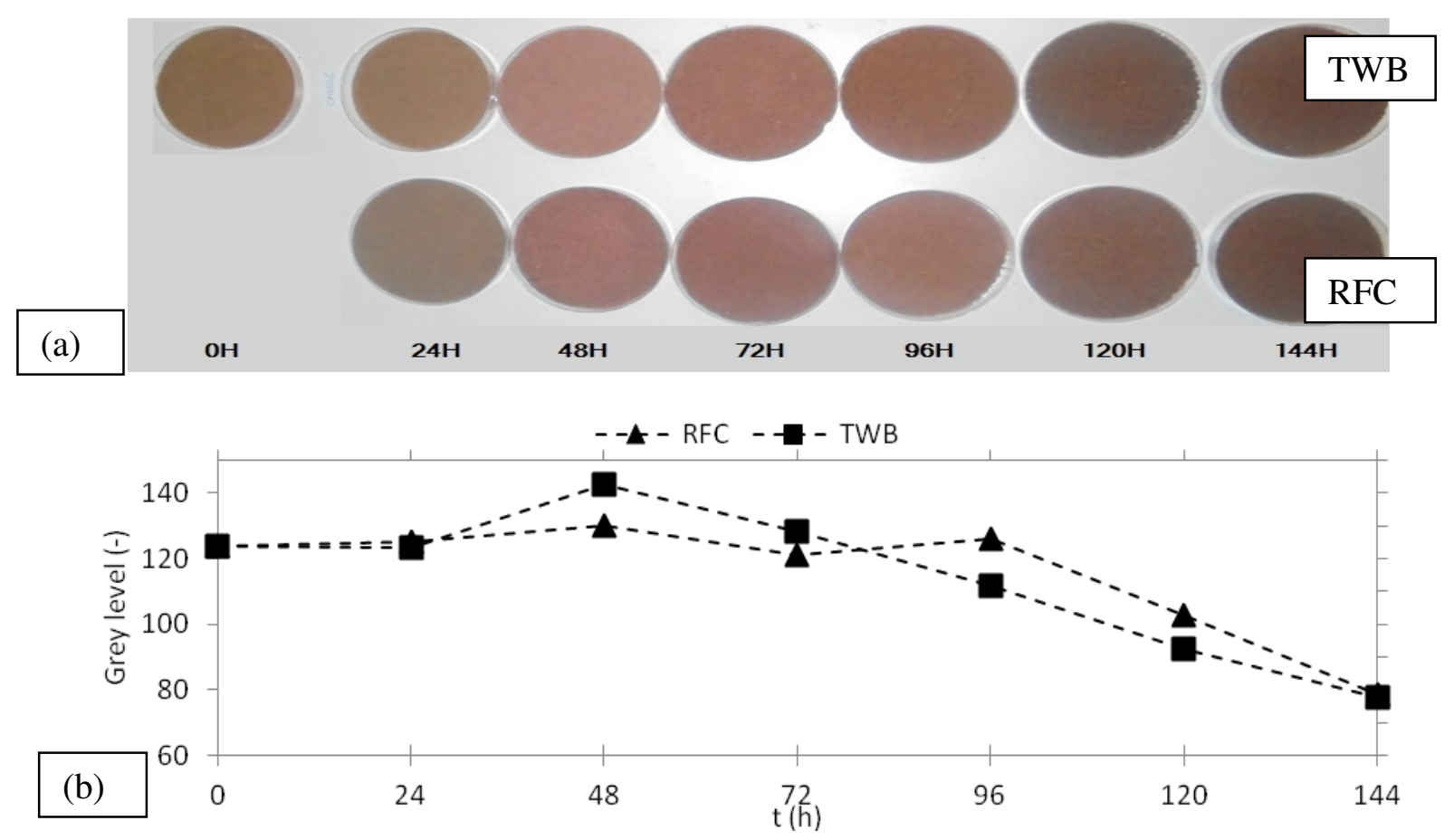

Fig 5: Evolution of nib browning during fermentation in each fermenter: (a) colour of nib powder from beans taken

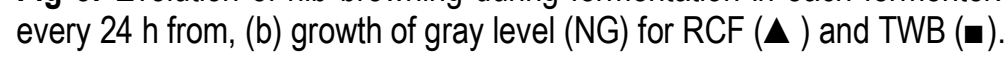

Fig shows the evolution of the coloring of the nib during the fermentation and according to the fermenter used. This coloring is translated by the gray level $(\mathrm{NC})$ of the pixels constituting the image taken with ImageJ $1.45 \mathrm{~s}$ software. Fig 5 indicates that, there is no modification in the coloring of the nib from 0 hours to 24 hours. From 24 hours to 48 hours, the changes are most intense throughout the process, with a more visible brightness for TWB. Then from 48 hours to 144 hours, there is a continuous darkening of the coloring of the nib with an almost identical final appearance for the two fermenters. The acidity and heat caused by the activity of germs was responsible of alteration inside the nib during fermentation. As Fig. 5 showed course of browning in both fermenters. The change in colour observed from $48 \mathrm{~h}$ was also observed by Nielsen, (2006) and is due to the hydrolysis of anthocyanins which are pigments insoluble (tannins) in coloring (anthcyanidins). This hydrolysis will increase throughout the fermentation with the increase in temperature and acidity in the nib. Indeed from $48 \mathrm{~h}$ the temperature of about $42^{\circ} \mathrm{C}$ observed and the acidity entered in the almond will initiate the melting of the lipids (Biehl et al., 1982) and break the cell walls which isolated polyphenols (Barel, 2013). They will be oxidized in the presence of air by the polyphenol oxidases and subsequently complexed to give tannin. This acidity of the nib with a pH of about 5 will promote the activity of the hydrolytic enzymes. This acidity of the nib with a pH of the activity of the hydrolytic enzymes will be 

materials for improvement of cocoa fermentation, in Ivory Coast

upgraded(Afoakwa et al., 2013; Biehl et al., 1993; Jinap, 1994). So, this difference in the evolution of coloring is explained by the difference in the

\section{CONCLUSION}

The overall results showed that cocoa fermented in three fermenters give different temperature values. The highest value was obtained in this experiments' fermenter (RCF). During fermentation, microbiota population growth differently but in the same order, and the value of averages in fermenter are close to other studies. It is noted that the insulation and the function of ACKNOWLEDGEMENT

We would like to thank the State of Côte d'Ivoire for the financing granted through the PreSeD-Ci and AMRUGE-Cl projects under the debt reduction contract, as well as the IRD and the French Embassy in Côte

\section{REFERENCE}

Afoakwa, E., Kongor, J., Takrama, J., Budu, A., others, 2013. Changes in nib acidification and biochemical composition during fermentation of pulp pre-conditioned cocoa (Theobroma cacao) beans. Int. Food Res. J. 20, 18431853.

Bankoff, L., Ouattara, G., Karou, T., Guehi, S.T., Nemlin, J., Diopoh, J., 2014. Impacts de la fermentation du cacao sur la croissance de la flore microbienne et la qualite des feves marchandes. Agron. Afr. 25, 159-170.

Barel, M., 2013. Qualité du cacao L'impact du traitement post-récolte, savoir faire. quae.

Biehl, B., Passern, D., Sagemann, W., 1982. Effect of acetic acid on subcellular structures of cocoa bean cotyledons. J. Sci. Food Agric. 33, 11011109.

Biehl, B., Voigt, J., Heinrichs, H., Senjuk, V., Bytof, G., 1993. pH-dependent enzymatic formation of oligopeptides and amino acids, the aroma precursors in raw cocoa beans, in: Xlth International Cocoa Research Conference. Cocoa Producers Alliance: Yamassoukro, Ivory Coast. pp. 717-722.

Braudeau, jean, 1973. Etude scientifique : le cacaoyer.

Camu, N., De Winter, T., Addo, S.K., Takrama, J.S., Bernaert, H., De Vuyst, L., 2008. Fermentation of cocoa beans: influence of microbial activities and polyphenol concentrations on the flavour of chocolate. J. Sci. Food Agric. 88, 2288-2297. temperature and acidity evolution between the two fermenters.

the fermenter was responsible for this difference in temperature. However, RCF induced a better quality of fermentation from four days. A change in the order of emergence of microbiota during fermentation leads to a delay in the beans browning. RCF was the solution to improve the quality of fermentation and guarantee chocolate flavour from day four.

d'Ivoire for the management of the obtained financing. At the same time, we would like to thank the SAB for the supply of plant material and the working site.

Crafack, M., Mikkelsen, M.B., Saerens, S., Knudsen, M., Blennow, A., Lowor, S., Takrama, J., Swiegers, J.H., Petersen, G.B., Heimdal, H., others, 2013. Influencing cocoa flavour using Pichia kluyveri and Kluyveromyces marxianus in a defined mixed starter culture for cocoa fermentation. Int. J. Food Microbiol. 167, 103116.

da Veiga Moreira, I.M., Miguel, M.G. da C.P., Duarte, W.F., Dias, D.R., Schwan, R.F., 2013. Microbial succession and the dynamics of metabolites and sugars during the fermentation of three different cocoa (Theobroma cacao L.) hybrids. Food Res. Int. 54, 9-17.

De Vuyst, L., Weckx, S., 2016. The cocoa bean fermentation process: from ecosystem analysis to starter culture development. J. Appl. Microbiol.

Dircks, H., 2009. Investigation into the fermentation of Australian cocoa beans and its effect on microbiology, chemistry and flavour. Univ. New South Wales Aust.

Grimaldi, J., 1978. owu. Café Cacao Thé 22, 303-316.

Guehi, S.T., Dabonne, S., Ban-Koffi, L., Kedjebo, D.K., Zahouli, G.I.B., 2010. Effect of turning beans and fermentation method on the acidity and physical quality of raw cocoa beans. Adv. J. Food Sci. Technol. 2, 163-171.

Guehi, T.S., Dadie, A.T., Koffi, K.P., Dabonne, S., BanKoffi, L., Kedjebo, K.D., Nemlin, G.J., 2010. 
Performance of different fermentation methods and the effect of their duration on the quality of raw cocoa beans. Int. J. Food Sci. Technol. $45,2508-2514$.

Hamdouche, Y., 2015. Discrimination des procédés de transformation post-récolte du Cacao et du Café par analyse globale de I écologie microbienne. Montpellier SupAgro.

Hatmi, R.U., Kobarsih, M., Cahyaningrum, N., 2015. Fungi level analysis of cocoa beans based on fermentation box type and duration. Procedia Food Sci. 3, 371-382. https://doi.org/10.1016/j.profoo.2015.01.041

Jinap, S., 1994. Organic acids in cocoa beans-a review. Koffi, A.S., Yao, N.G., Bastide, P., Bruneau, D., Kadjo, D., 2017. Homogenization of Cocoa Beans Fermentation to Upgrade Quality Using an Original Improved Fermenter. Int. J. Biol. Biomol. Agric. Food Biotechnol. Eng. 11, 558563.

Kongor, J.E., Takrama, J.F., Budu, A.S., MensahBrown, H., Afoakwa, E.O., 2013. Effects of fermentation and drying on the fermentation index and cut test of pulp pre-conditioned Ghanaian cocoa (Theobroma cacao) beans. J. Food Sci. Eng. 3, 625.

Nielsen, D.S., 2006. The microbiology of Ghanaian cocoa fermentations. Københavns Universitet'Københavns Universitet', LUKKET: 2012 Det Biovidenskabelige Fakultet for Fødevarer, Veterinla ermedicin og NaturressourcerFaculty of Life Sciences, LUKKET: 2012 Institut for Fødevarevidenskab Department of Food Science, 2012 Institut for Fødevarevidenskab, 2012 Fødevaremikrobiologi Department of Food Science, Food Microbiology.

Nielsen, D.S., Teniola, O., Ban-Koffi, L., Owusu, M., Andersson, T., Holzapfel, W., 2007. The microbiology of Ghanaian cocoa fermentations analysed using culture-dependent and cultureindependent methods. Int. J. Food Microbiol. 114, 168-186.

Ouattara, D.H., Ouattara, H.G., Goualie, B.G., Kouame, L.M., Niamke, S.L., 2014. Biochemical and functional properties of lactic acid bacteria isolated from Ivorian cocoa fermenting beans. J. Appl. Biosci. 77, 6489-6499.

Torres-Moreno, M., Torrescasana, E., Salas-Salvadó, J., Blanch, C., 2015. Nutritional composition and fatty acids profile in cocoa beans and chocolates with different geographical origin and processing conditions. Food Chem. 166, 125-132. 